\title{
Possibilities of using products containing amino acids in the protection of roses against Podosphaera pannosa and their influence on plant development
}

\author{
Możliwość wykorzystania środków zawierających aminokwasy \\ w ochronie róż przed Podosphaera pannosa oraz ich wpływ na rozwój roślin
}

\author{
Adam Wojdyła*
}

\section{Summary}

The study assessed the influence of the plant growth promoter Agro-Sorb Folium and foliar fertilizers Agro-Sorb L-Amino and Agro-Sorb Radiculum, used 4 times at 7-day intervals as foliar spray application on roses grown in a greenhouse, on the development of disease symptoms caused by Podosphaera pannosa. Agro-Sorb Folium and Agro-Sorb L-Amino were applied at the concentrations of $0.25,0.5$ and $1 \%$. Their effectiveness ranged from 64 to $98 \%$. An increase in the concentration of the tested products caused an increase in their effectiveness. Agro-Sorb Radiculum used at the concentration of $0.5 \%$ showed an effectiveness of about $85 \%$. The fertilizers Agro-Sorb L-amino and Agro-Sorb Radiculum showed an effectiveness of $21.7 \%$ and $64 \%$, respectively after a 2 -fold watering treatment, and $17 \%$ and $10 \%$ after a 4 -fold applications. All the tested products used as foliar or watering application caused significant stimulation of the growth of rose shrubs. None of the products caused changes in the appearance of roses (phytotoxicity).

Key words: Podosphaera pannosa; Rosa sp.; rose; powdery mildew; amino acids; effectiveness

\section{Streszczenie}

Oceniano wpływ stymulatora wzrostu roślin Agro-Sorb Folium, nawozów dolistnych Agro-Sorb L-Amino oraz Agro-Sorb Radiculum, stosowanych 4-krotnie co 7 dni do opryskiwania róż uprawianych w szklarni, na rozwój choroby powodowanej przez Podosphaera pannosa. Agro-Sorb Folium oraz Agro-Sorb L-Amino aplikowano w stężeniu 0,25; 0,5 oraz 1\%. Ich skuteczność wynosiła od 64 do $98 \%$. Wzrost stężenia badanych środków powodował zwiększenie ich skuteczności. Agro-Sorb Radiculum w stężeniu 0,5\%, zastosowany do opryskiwania róż, wykazywał około 85\% skuteczności. Nawozy Agro-Sorb L-Amino oraz Agro-Sorb Radiculum po 2-krotnym podlaniu róż wykazywały $21,7 \%$ oraz $64 \%$ skuteczności, a po 4-krotnym odpowiednio $10 \%$ i $17 \%$. Wszystkie badane środki stosowane do opryskiwania lub podlewania powodowały istotną stymulację wzrostu krzewów róż. Żaden z badanych środków nie powodował zmian w wyglądzie róż (fitotoksyczności).

Słowa kluczowe: Podosphaera pannosa; Rosa sp.; róża; mączniak prawdziwy; aminokwasy; skuteczność

Instytut Ogrodnictwa

Konstytucji 3 Maja 1/3, 96-100 Skierniewice

*corresponding author: adam.wojdyla@inhort.pl 


\section{Wstęp / Introduction}

Mączniak prawdziwy powodowany przez grzyb Podosphaera pannosa (Wall.: Fr.) de Bary jest jedną z najczęściej występujących i najgroźniejszych chorób róży (Rosa sp.) (Wojdyła 2000). Podstawową metodą ograniczenia jej występowania jest stosowanie syntetycznych fungicydów (Wojdyła 2008). Ich częste użycie wiąże się z wysokimi kosztami ochrony, nierzadko z hamowaniem wzrostu roślin, skażeniem środowiska oraz powstawaniem odporności patogenów na stosowane fungicydy.

Możliwością wykorzystania aminokwasów w ochronie roślin przed patogenami zajmowano się już w drugiej połowie 20. wieku, kiedy po raz pierwszy wykazano, że odmiany jabłoni podatne na Venturia inaequalis po wstrzyknięciu do ogonków liściowych aminokwasu fenyloalaniny wykazały odporność na ten gatunek (Kuć i wsp. 1959). Van Andel (1966) opisuje terapeutyczny efekt aminokwasów względem Aphanomyces euteiches, Botrytis fabae, Cladosporium cucumerinum, Colletotrichum lagenarium, Erysiphe cichoracearum, Phytophthora infestans, Phytophthora cinnamomi, Puccinia recondita f. sp. tritici, Puccinia graminis f. sp. tritici i Venturia inaequalis. W późniejszych latach wykazano również możliwość stosowania aminokwasów w ochronie: cytryny przed Xanthomonas citri subsp. citri (Hasabi i wsp. 2014), bawełny przed Fusarium oxysporum f. sp. vasinfectum (Aly i wsp. 2010), pomidora przed Fusarium oxysporum f. sp. lycopersici (Woltz i Jones 1970), prosa przed Sclerospora graminicola (Sarosh i wsp. 2005) oraz ryżu przed Pyricularia oryzae (Homma i wsp. 1973; Kadotani i wsp. 2016). Wykazano, że aminokwasy mogą być pobierane przez roślinę bez uprzedniej ich mineralizacji przez mikroorganizmy (Lipson i Nasholem 2001). Wprowadzone na powierzchnię rośliny w czasie opryskiwania są łatwo absorbowane przez komórki, stanowiąc gotowy produkt dla różnych procesów metabolicznych (El-Ghamry i wsp. 2009). Van Andel (1966) wyjaśniając mechanizm działania aminokwasów na czynniki chorobotwórcze, wskazuje na ich działanie grzybobójcze, obniżenie agresywności (wirulencji) patogenów, produkcję innych związków w glebie lub roślinie, zaburzenia metabolizmu azotu, ingerencję w ekspresję objawów i zwiększenie odporności rośliny na patogeny. W zależności od czynnika chorobotwórczego oraz rośliny gospodarza aminokwasy mogą przyśpieszyć (Booth 1969; Singh i wsp. 1971) lub opóźnić (Hrushrovetz 1957) patogenezę. Dotychczasowe badania nad indukcją przez aminokwasy odporności roślin na patogeny są bardzo ograniczone. Hasabi i wsp. (2014) w swoich badaniach nad rakiem bakteryjnym cytryny ( $X$. citri subsp. citri) wykazali, że L-metionina istotnie ograniczała rozwój nekrozy na liściach oraz powodowała wzrost zawartości enzymów, w tym: katalazy, peroksydazy i 1,3- $\beta$ glukanazy. Badania nad wpływem aminokwasów na syntezę enzymów proteolitycznych (proteaz) i celuloitycznych przeprowadzili Mehta i wsp. (1991). W przypadku Fusarium oxysporum i Fusarium moniliforme leucyna i fenyloalanina całkowicie hamowały syntezę polygalakturonazy (PG) enzymu odpowiedzialnego za rozkład ścian komórkowych roślin. Z kolei takie aminokwasy, jak leucyna, fenylo- alanina i tryptofan całkowicie hamowały syntezę celulazy przez $F$. moniliforme, a także ograniczały jej syntezę w przypadku $F$. oxysporum.

Celem badań było określenie skuteczności środków zawierających naturalne aminokwasy w ograniczaniu rozwoju mączniaka prawdziwego róży ( $P$. pannosa), a także ich wpływu na wzrost roślin.

\section{Materiały i metody / Materials and methods}

W badaniach uwzględniono środki, których głównym składnikiem są wolne, naturalne (L- $\alpha$ ) aminokwasy (histydyna, seryna, arginina, glicyna, kwas asparaginowy, kwas glutaminowy, treonina, alanina, prolina, cysteina, lizyna, tyrozyna, metionina, walina, izoleucyna, leucyna, fenyloalanina, tryptofan), tj. stymulator wzrostu roślin Agro-Sorb Folium [aminokwasy ogółem 12\%, w tym wolne aminokwasy $9,3 \%+$ azot całkowity (N) $2,1 \%+$ bor (B) $0,02 \%+$ mangan $(\mathrm{Mn}) 0,05 \%+$ cynk $(\mathrm{Zn})$ 0,07\%], nawóz organiczny: Agro-Sorb L-Amino [aminokwasy ogółem $10 \%$, w tym wolne aminokwasy $5 \%+$ azot całkowity (N) $2 \%+$ azot organiczny $\left(\mathrm{N}_{\text {org }}\right) 2 \%+$ węgiel organiczny $\left(\mathrm{C}_{\text {org }}\right) 4 \%+$ substancje organiczne w suchej masie $65 \%$ ] oraz nawóz organiczno-mineralny: Agro-Sorb Radiculum [aminokwasy ogółem 7\%, w tym wolne aminokwasy $6 \%+$ azot całkowity (N) $2,9 \%+$ fosfor $\left(\mathrm{P}_{2} \mathrm{O}_{5}\right) 1 \%+$ substancje organiczne w suchej masie $70 \%+$ sucha masa 20\%] w ochronie przed mączniakiem prawdziwym oraz ich wpływ na wzrost krzewów.

W sezonie wegetacyjnym 2016 przeprowadzono 2 razy doświadczenia na róży (Rosa sp.) odmiany Aga posadzonej do pojemników (ll) ustawionych na parapecie w szklarni. W czasie prowadzenia doświadczeń w szklarni utrzymywano wilgotność powietrza około $70 \%$, a temperatura wahała się pomiędzy 17 a $24^{\circ} \mathrm{C}$. Rośliny podlewano, kierując strumień wody bezpośrednio do doniczek lub na matę podsiąkową, na której były ustawione pojemniki.

Po wystąpieniu objawów choroby badane środki zastosowano do 4-krotnego, cotygodniowego opryskiwania lub podlewania roślin $\mathrm{W}$ stężeniach podanych $\mathrm{w}$ tabeli 1 . Rośliny kontrolne opryskiwano wodą bez dodatku środków. Jako środek standardowy użyto Domark 100 EC (100 g tetrakonazolu w 1 l). Rośliny kontrolne opryskiwano wodą, a pozostałe badanymi środkami w różnych stężeniach, zużywając $100 \mathrm{ml}$ cieczy na $1 \mathrm{~m}^{2}$. Z kolei do podlewania roślin stosowano $50 \mathrm{ml}$ cieczy na doniczkę.

Przed rozpoczęciem doświadczenia oraz po 3 dniach od wykonania 2- i 4-krotnego opryskiwania wykonano obserwacje nasilenia objawów chorobowych według 6-stopniowej skali (tab. 1, 2). Obserwacje dotyczące ewentualnej fitotoksyczności badanych środków prowadzono po 3 dniach od wykonania każdego opryskiwania. Podczas obserwacji zwracano uwagę, czy nie wystąpiły objawy żółknięcia, zbrązowienia tkanek roślinnych lub zahamowania wzrostu.

Przed rozpoczęciem doświadczenia zmierzono również wysokość oraz policzono pędy na roślinie. Po 3 dniach od wykonania czwartego opryskiwania zmierzono wysokość roślin, określono liczbę pędów na roślinie oraz zważono nadziemną i podziemną część świeżej i suchej masy w zależności od użytego środka i stężenia (tab. 3). Z każ- 
dego powtórzenia oddzielnie wyciągano rośliny z podłoża, a następnie pod bieżącą wodą z systemu korzeniowego usuwano jego resztki. Przed zważeniem rośliny osuszano kilkakrotnie bibułą filtracyjną. Za pomocą sekatora oddzielano część nadziemną od podziemnej i zważono w celu określenia świeżej masy dla każdego powtórzenia. Po podzieleniu przez liczbę roślin z powtórzenia uzyskiwano dane świeżej masy dla pojedynczej rośliny. Następnie po umieszczeniu $\mathrm{w}$ kopertach $\mathrm{z}$ poszczególnych powtórzeń części nadziemnych i podziemnych przetrzymywano je w temperaturze $70^{\circ} \mathrm{C}$ przez okres 24 godzin w cieplarkach o wymuszonym obiegu powietrza. Po wyjęciu z cieplarki materiał roślinny ponownie zważono wraz z kopertami i bez. Końcową suchą masę dla części nadziemnych i podziemnych podzielono przez liczbę roślin w powtórzeniu (5 szt.), aby uzyskać wyniki w przeliczeniu na jedną roślinę.

Doświadczenia założono w układzie bloków kompletnie losowanych, w 4 powtórzeniach po 5 krzewów róż. Uzyskane dane poddano analizie statystycznej, stosując test Duncana. Następnie obliczono procent ograniczenia natężenia wielkości objawów mączniaka prawdziwego w stosunku do obiektu kontrolnego (niechronionego), posługując się uproszczonym wzorem Abbotta (Abbott 1925).

\section{Wyniki i dyskusja / Results and discussion}

\section{Wpływ stymulatora wzrostu i badanych nawozów na ochronę róż przed mączniakiem prawdziwym}

W pierwszym doświadczeniu, po 2-krotnym opryskiwaniu, na roślinach kontrolnych stopień porażenia krzewów wynosił 2,5 (tab. 1). Skuteczność badanych środków, stosowanych do opryskiwania roślin wynosiła od 84\% (Agro-Sorb L-Amino w stęż. 0,25\% i Agro-Sorb Radiculum w stęż. 0,5\%) do 100\% (Agro-Sorb Folium W stęż. 1\%). Po 4-krotnym opryskiwaniu na roślinach kontrolnych stopień porażenia krzewów wynosił 5,0 (tab. 1). W tym samym czasie skuteczność badanych środków wynosiła od 64\% (Agro-Sorb L-Amino w stęż. 0,25\%) do 98\% (Agro-Sorb Folium w stęż. 1\%). Badania wykazały, że w każdej z przeprowadzonych obserwacji wzrost stężenia środka Agro-Sorb Folium oraz Agro-Sorb L-Amino, użytych do opryskiwania róż, wiązał się z istotnym wzrostem ich skuteczności.

Agro-Sorb L-Amino oraz Agro-Sorb Radiculum, stosowane do podlewania roślin, po 2-krotnym zabiegu wykazywały 64\% skuteczności, a po 4-krotnym, przy bardzo dużym nasileniu objawów, odpowiednio 17\% i 10\%.

$\mathrm{W}$ drugim doświadczeniu, po 2-krotnym opryskiwaniu, na roślinach kontrolnych stopień porażenia krzewów wynosił 4,6 (tab. 2). Skuteczność badanych środków stosowanych do opryskiwania roślin wynosiła od 60,9\% (Agro-Sorb Folium w stęż. 0,25\%) do 75\% (Agro-Sorb L-Amino w stęż. 1\%). Po 4-krotnym opryskiwaniu stopień porażenia krzewów kontrolnych wynosił 5,0 (tab. 2). W tym samym czasie skuteczność badanych środków wynosiła od 57\% (Agro-Sorb Folium w stęż. 0,25\%) do $87 \%$ (Agro-Sorb L-Amino w stęż. 1\%). W każdej z przeprowadzonych obserwacji wzrost stężenia środka Agro-Sorb Folium oraz Agro-Sorb L-Amino, użytych do opryskiwania róż, wiązał się z poprawą ich skuteczności.

Tabela 1. Skuteczność Agro-Sorb Folium, Agro-Sorb L-Amino oraz Agro-Sorb Radiculum w ograniczaniu rozwoju mączniaka prawdziwego róż odmiany Aga uprawianych w szklarni

Table 1. Effectiveness of Agro-Sorb Folium, Agro-Sorb L-Amino and Agro-Sorb Radiculum in controlling the development of powdery mildew on roses cultivar Aga grown in a greenhouse

Początek doświadczenia i porażenie wstępne: 01.04.2016 $=0,25$

Experiment start date and initial degree of infection: April 1, 2016 $=0.25$

\begin{tabular}{l|c|c|c|c|c}
\hline \multirow{2}{*}{$\begin{array}{c}\text { Kombinacja } \\
\text { Treatment }\end{array}$} & $\begin{array}{c}\text { Stężenie } \\
\text { Concentration } \\
{[\%]}\end{array}$ & $\begin{array}{c}\text { Stopień porażenia roślin } \\
\text { po opryskiwaniach } \\
\text { Degree of rose shrubs infection } \\
\text { after spraying }\end{array}$ & \multicolumn{2}{|c}{$\begin{array}{c}\text { Procentowa skuteczność } \\
\text { po opryskiwaniach } \\
\text { Effectiveness after spraying } \\
{[\%]}\end{array}$} \\
\cline { 3 - 6 } & & 2 & 4 & 2 & 4 \\
Kontrola - Control & - & $2,50 \mathrm{a}$ & $5,00 \mathrm{a}$ & 0,00 & 0,00 \\
Agro-Sorb Folium & 0,25 & $0,25 \mathrm{~cd}$ & $1,50 \mathrm{e}$ & 90 & 70 \\
Agro-Sorb Folium & 0,5 & $0,10 \mathrm{de}$ & $0,65 \mathrm{fg}$ & 96 & 87 \\
Agro-Sorb Folium & 1,0 & $0,00 \mathrm{e}$ & $0,10 \mathrm{~h}$ & 100 & 98 \\
Agro-Sorb L-Amino & 0,25 & $0,40 \mathrm{c}$ & $1,80 \mathrm{~d}$ & 84 & 64 \\
Agro-Sorb L-Amino & 0,5 & $0,10 \mathrm{de}$ & $1,40 \mathrm{e}$ & 96 & 72 \\
Agro-Sorb L-Amino & 1,0 & $0,05 \mathrm{e}$ & $0,50 \mathrm{~g}$ & 98 & 90 \\
Agro-Sorb L-Amino* & $0,8 *$ & $0,90 \mathrm{~b}$ & $4,15 \mathrm{c}$ & 64 & 17 \\
Agro-Sorb Radiculum & 0,5 & $0,40 \mathrm{c}$ & $0,80 \mathrm{f}$ & 84 & 84 \\
Agro-Sorb Radiculum* & $0,8 *$ & $0,90 \mathrm{~b}$ & $4,50 \mathrm{~b}$ & 64 & 10 \\
Domark 100 EC & 0,05 & $0,00 \mathrm{e}$ & $0,00 \mathrm{~h}$ & 100 & 100 \\
\hline
\end{tabular}

*podlewanie - irigation

Średnie oznaczone tą samą literą dla poszczególnych kolumn nie różnią się istotnie (5\%) według testu Duncana

Means in each column followed by the same letter do not differ at the $5 \%$ level of significance (Duncan's multiple range test)

Skala porażenia: 0 - brak objawów; 1 - do $1 \%$ powierzchni pędów/liści pokrytej grzybnią; 2 - 1,1 do $5 \% ; 3$ - 5,1 do $10 \% ; 4$ - 10,1 do $20 \% ; 5$ - powyżej $20 \%$ powierzchni pędów/liści pokrytej grzybnią

Degree of infection: 0 - no symptoms; 1 - up to $1 \%$ of stem/leaf surface covered with mycelium; $2-1.1$ to $5 \% ; 3-5.1$ to $10 \% ; 4-10.1$ to $20 \% ; 5-$ more than $20 \%$ of stem/leaf surface covered with mycelium 
Tabela 2. Skuteczność Agro-Sorb Folium, Agro-Sorb L-Amino oraz Agro-Sorb Radiculum w ograniczaniu rozwoju mączniaka prawdziwego róż odmiany Aga uprawianych w szklarni

Table 2. Effectiveness of Agro-Sorb Folium, Agro-Sorb L-Amino and Agro-Sorb Radiculum in controlling the development of powdery mildew on roses cultivar Aga grown in a greenhouse

Początek doświadczenia i porażenie wstępne: 23.05.2016 =0,1

Experiment start date and initial degree of infection: May 23, $2016=0.1$

\begin{tabular}{|c|c|c|c|c|c|}
\hline \multirow[t]{2}{*}{$\begin{array}{c}\text { Kombinacja } \\
\text { Treatment }\end{array}$} & \multirow[t]{2}{*}{$\begin{array}{c}\text { Stężenie } \\
\text { Concentration } \\
{[\%]}\end{array}$} & \multicolumn{2}{|c|}{$\begin{array}{c}\text { Stopień porażenia roślin } \\
\text { po opryskiwaniach } \\
\text { Degree of rose shrubs infection } \\
\text { after spraying }\end{array}$} & \multicolumn{2}{|c|}{$\begin{array}{c}\text { Procentowa skuteczność } \\
\text { po opryskiwaniach } \\
\text { Effectiveness after spraying } \\
{[\%]}\end{array}$} \\
\hline & & 2 & 4 & 2 & 4 \\
\hline Kontrola - Control & - & $4,60 \mathrm{a}$ & $5,00 \mathrm{a}$ & 0,0 & 0,0 \\
\hline Agro-Sorb Folium & 0,25 & $1,80 \mathrm{~d}$ & $2,15 \mathrm{c}$ & 60,9 & 57 \\
\hline Agro-Sorb Folium & 0,5 & $1,65 \mathrm{e}$ & $1,60 \mathrm{~d}$ & 64,1 & 68 \\
\hline Agro-Sorb Folium & 1,0 & $1,35 \mathrm{f}$ & $0,80 \mathrm{f}$ & 70,6 & 84 \\
\hline Agro-Sorb L-Amino & 0,25 & $1,45 \mathrm{f}$ & $1,55 \mathrm{~d}$ & 68,5 & 69 \\
\hline Agro-Sorb L-Amino & 0,5 & $1,35 \mathrm{f}$ & $1,20 \mathrm{e}$ & 70,6 & 76 \\
\hline Agro-Sorb L-Amino & 1,0 & $1,15 \mathrm{~g}$ & $0,65 \mathrm{f}$ & 75,0 & 87 \\
\hline Agro-Sorb L-Amino* & $0,8^{*}$ & $3,60 \mathrm{~b}$ & $4,40 \mathrm{~b}$ & 21,7 & 12 \\
\hline Agro-Sorb Radiculum & 0,5 & $1,35 \mathrm{f}$ & $0,70 \mathrm{f}$ & 70,6 & 86 \\
\hline Agro-Sorb Radiculum* & $0,8^{*}$ & $3,40 \mathrm{c}$ & $4,40 \mathrm{~b}$ & 26,1 & 12 \\
\hline Domark $100 \mathrm{EC}$ & 0,05 & $0,30 \mathrm{~h}$ & $0,30 \mathrm{~g}$ & 93,5 & 94 \\
\hline
\end{tabular}

*podlewanie - irigation

Średnie oznaczone tą samą literą dla poszczególnych kolumn nie różnią się istotnie (5\%) według testu Duncana

Means in each column followed by the same letter do not differ at the $5 \%$ level of significance (Duncan's multiple range test)

Tabela 3. Wpływ stymulatora wzrostu roślin Agro-Sorb Folium oraz nawozów Agro-Sorb L-Amino i Agro-Sorb Radiculum na wzrost krzewów róż odmiany Aga uprawianych w szklarni

Table 3. Influence of the growth promoter Agro-Sorb Folium and fertilizers Agro-Sorb L-Amino and Agro-Sorb Radiculum on the growth of rose shrubs cultivar Aga grown in a greenhouse

Obserwacja po 14 dniach od wykonania ostatniego opryskiwania - Observations 14 days after the last treatment

Początek doświadczenia: 01.04.2016 - Experiment start date: April 1, 2016

Początkowa liczba liści na roślinie - 4,71; wysokość roślin $-75 \mathrm{~mm}$

Initial number of leaves per plant -4.71 ; plant height $-75 \mathrm{~mm}$

\begin{tabular}{|c|c|c|c|c|c|c|c|}
\hline $\begin{array}{c}\text { Kombinacja } \\
\text { Treatment }\end{array}$ & $\begin{array}{c}\text { Stężenie } \\
\text { Concentration } \\
{[\%]}\end{array}$ & $\begin{array}{l}\text { Wysokość } \\
\text { roślin } \\
\text { Plants' height } \\
\text { [mm] }\end{array}$ & $\begin{array}{c}\text { Średnia liczba } \\
\text { pędów } \\
\text { na roślinie } \\
\text { Average } \\
\text { amount } \\
\text { of stems } \\
\text { on plant }\end{array}$ & $\begin{array}{c}\text { Masa części } \\
\text { nadziemnych } \\
\text { Mass } \\
\text { of above-ground } \\
\text { parts } \\
\text { [g] }\end{array}$ & $\begin{array}{c}\text { Sucha masa } \\
\text { części } \\
\text { nadziemnych } \\
\text { Dray mass } \\
\text { of above-ground } \\
\text { parts } \\
{[\mathrm{g}]} \\
\end{array}$ & $\begin{array}{c}\text { Masa } \\
\text { korzeni } \\
\text { Mass } \\
\text { of roots } \\
{[\mathrm{g}]}\end{array}$ & $\begin{array}{c}\text { Sucha } \\
\text { masa } \\
\text { korzeni } \\
\text { Dray mass } \\
\text { of roots } \\
{[\mathrm{g}]}\end{array}$ \\
\hline Kontrola - Control & - & $182,5 \mathrm{~h}$ & $2,50 \mathrm{~d}$ & $3,15 \mathrm{~g}$ & $0,90 \mathrm{i}$ & $0,77 \mathrm{~d}$ & $0,20 \mathrm{~cd}$ \\
\hline Agro-Sorb Folium & 0,25 & $201,3 \mathrm{~g}$ & $2,85 \mathrm{bc}$ & $3,45 \mathrm{f}$ & $0,94 \mathrm{~h}$ & $0,66 \mathrm{e}$ & $0,18 \mathrm{~d}$ \\
\hline Agro-Sorb Folium & 0,5 & $211,8 \mathrm{e}$ & $2,95 \mathrm{ab}$ & $4,20 \mathrm{c}$ & $1,03 \mathrm{f}$ & $0,75 \mathrm{~d}$ & $0,20 \mathrm{~cd}$ \\
\hline Agro-Sorb Folium & 1,0 & $238,5 \mathrm{a}$ & $3,25 \mathrm{a}$ & $4,25 \mathrm{c}$ & $1,12 \mathrm{~d}$ & $1,24 \mathrm{a}$ & $0,28 \mathrm{~b}$ \\
\hline Agro-Sorb L-Amino & 0,25 & $203,0 \mathrm{~g}$ & $2,55 \mathrm{~cd}$ & $3,87 \mathrm{~d}$ & 1,05 ef & $0,83 \mathrm{c}$ & $0,20 \mathrm{~cd}$ \\
\hline Agro-Sorb L-Amino & 0,5 & $214,8 \mathrm{~d}$ & $2,90 \mathrm{~b}$ & $4,16 \mathrm{c}$ & $1,09 \mathrm{de}$ & $1,06 \mathrm{~b}$ & $0,28 \mathrm{~b}$ \\
\hline Agro-Sorb L-Amino & 1,0 & $231,3 \mathrm{~b}$ & $2,95 \mathrm{ab}$ & $4,28 \mathrm{c}$ & $1,10 \mathrm{~d}$ & $1,26 \mathrm{a}$ & $0,32 \mathrm{a}$ \\
\hline Agro-Sorb L-Amino* & $0,8^{*}$ & $204,5 \mathrm{fg}$ & $2,85 \mathrm{bc}$ & $3,69 \mathrm{e}$ & $0,99 \mathrm{~g}$ & $1,05 \mathrm{~b}$ & $0,27 \mathrm{~b}$ \\
\hline Agro-Sorb Radiculum & 0,5 & $227,0 \mathrm{c}$ & $2,90 \mathrm{~b}$ & $4,50 \mathrm{~b}$ & $1,23 \mathrm{~b}$ & $1,11 \mathrm{~b}$ & $0,26 \mathrm{~b}$ \\
\hline Agro-Sorb Radiculum* & $0,8^{*}$ & $229,3 \mathrm{bc}$ & $3,00 \mathrm{ab}$ & $4,92 \mathrm{a}$ & $1,27 \mathrm{a}$ & $1,21 \mathrm{a}$ & $0,27 \mathrm{~b}$ \\
\hline Domark 100 EC & 0,05 & $206,8 \mathrm{f}$ & $2,75 b-d$ & $4,58 \mathrm{~b}$ & $1,18 \mathrm{c}$ & $1,26 \mathrm{a}$ & $0,23 \mathrm{c}$ \\
\hline
\end{tabular}

*podlewanie - irigation

Średnie oznaczone tą samą literą dla poszczególnych kolumn nie różnią się istotnie (5\%) według testu Duncana

Means for each column followed by the same letter do not differ at $5 \%$ level of significance (Duncan's multiple range test)

Agro-Sorb L-Amino oraz Agro-Sorb Radiculum zastosowane do 2-krotnego podlewania roślin wykazywały $21,7 \%$ oraz $26,1 \%$ skuteczności, a po 4-krotnym podlewaniu, przy bardzo dużym nasileniu objawów, ich skuteczność wynosiła $12 \%$. 


\section{Wpływ stymulatora wzrostu i badanych nawozów na wzrost roślin}

Wszystkie badane środki stosowane do opryskiwania oraz podlewania, stymulowały wzrost roślin (tab. 3). Jedynie na krzewach opryskiwanych Agro-Sorb L-Amino w stężeniu 0,25\% stwierdzono podobną liczbę pędów oraz suchą masę korzeni, jak na roślinach kontrolnych. Wykazano również, że świeża i sucha masa korzeni róż opryskiwanych Agro-Sorb Folium w stężeniu 0,25 i 0,5\% była podobna lub mniejsza w porównaniu do roślin kontrolnych.

Rośliny opryskiwane fungicydem Domark 100 EC miały istotnie wyższą wysokość, świeżą i suchą masę części nadziemnych, świeżą masę korzeni oraz statystycznie podobną liczbę pędów na roślinie oraz suchą masę korzeni w porównaniu z krzewami kontrolnymi.

Możliwość wykorzystania aminokwasów do ograniczania rozwoju mączniaka prawdziwego na różach znajduje swoje potwierdzenie w literaturze i badaniach przeprowadzonych przez innych autorów. Tzeng i wsp. (1996) oraz Sarosh i wsp. (2005) wskazują na możliwość zastosowania aminokwasu L-metioniny oraz ryboflawiny w ochronie dyni, grochu, kantalupy, melona i truskawki przed mączniakiem prawdziwym lub rzekomym. Mieszanina aminokwasu $\mathrm{z}$ witaminą powodowała indukcję odporności $\mathrm{w}$ chronionych roślinach. Dane literaturowe wskazują, że aminokwasy w sposób bezpośredni oddziaływują na kiełkowanie zarodników, wydłużanie strzępki kiełkowej oraz syntezę i aktywność niektórych enzymów odpowiedzialnych za patogenezę Fusarium spp. (Bakry i Rizk 1967), przyczyniając się w ten sposób do ograniczenia źródła patogena.
Niniejsze badania nie potwierdziły doniesień literaturowych na temat ewentualnej fitotoksyczności na roślinach po aplikacji aminokwasów. Jednakże we wcześniejszych badaniach stosowana na rośliny L-izoleucyna powodowała zahamowanie ich wzrostu, utratę wierzchołkowej dominacji i rozwój pędów bocznych oraz nienormalny kształt liści (Van Andel 1966 za Steinberg 1950, 1952). Inne badane przez wymienionych autorów L-aminokwasy wpływały na zmianę kształtu blaszki liściowej, a D-aminokwasy powodowały chlorozę i plamistości liści.

\section{Wnioski / Conclusions}

1. Stymulator wzrostu Agro-Sorb Folium oraz nawozy Agro-Sorb L-Amino i Agro-Sorb Radiculum, których głównym składnikiem są aminokwasy, użyte do ochrony róż wykazywały bardzo wysoką skuteczność w ograniczaniu rozwoju mączniaka prawdziwego.

2. Wraz ze wzrostem stężenia Agro-Sorb Folium i AgroSorb L-Amino stwierdzono wzrost ich skuteczności.

3. Nawozy Agro-Sorb L-Amino oraz Agro-Sorb Radiculum stosowane do 2-krotnego podlewania roślin wykazywały kilkudziesięcioprocentową skuteczność, a po 4-krotnym, przy bardzo dużym nasileniu objawów, ich skuteczność zdecydowanie się obniżyła.

4. Badany stymulator wzrostu oraz nawozy stosowane do opryskiwania lub podlewania powodowały istotną stymulację wzrostu krzewów róż.

5. Badany stymulator wzrostu oraz nawozy stosowane do opryskiwania lub podlewania nie powodowały żadnych zmian w wyglądzie róż (fitotoksyczności).

\section{Literatura / References}

Abbott W.S. 1925. A method of computing the effectiveness of an insecticide. Journal of Economic Entomology 18:265-267.

Aly A.A., Hussein E.M., Omar M.R., Abd-Elsalam K.A. 2010. Effects of amino acids in cotton seeds against the resistance to Fusarium wilt diseases. Allelopathy Journal 26 (1): 83-89.

Bakry M.A., Rizk R.H. 1967. Seed transmission of Fusarium oxysporum f. sp. vasinfectum, the causal agent of cotton wilt in the United Arab Republic. Agricultural Research Review (Cairo) 45: 1-4.

Booth J.A. 1969. Gossypium tolerance to Verticillium albo-atrum infection. I. Amino acid exudation from aseptic roots of tolerant and susceptible cotton. Phytopathology 59: 43-46.

El-Ghamry A.M., Abd El-Hai K.M., Ghoneem K.M. 2009. Amino and humic acids promote growth, yield and disease resistance of faba bean cultivated in clay soil. Australian Journal of Basic and Applied Sciences 3 (2): 731-739.

Hasabi V., Askari H., Alavi S.M., Zamanizadeh H. 2014. Effect of amino acid application on induced resistance against citrus canker disease in lime plants. Journal of Plant Protection Research 54 (2): 144-149.

Homma Y., Shida T., Misato T. 1973. Studies on the control of plant diseases by amino acid derivatives. (1) Effect of N-lauroyl-L-valine on rice blast. Annales of the Phtopathological Society of Japan 39 (2): 90-98.

Hrushrovetz S.B. 1957. Effect of amino acids on the virulence of Helmintosporium sativum to wheat seedlings. Phytopathology 47: 261-264.

Kadotani N., Akagi A., Takatsuji H., Miwa T., Igarashi D. 2016. Exogenous proteinogenic amino acid induce systemic resistance in rice. BMC Plant Biology 16 (1): 60.

Kuć J., Barnes E., Daftsios A., Williams E.B. 1959. The effect of amino acids on susceptibility of apple varieties to scab. Phytopathology 49: 313-315.

Lipson D.A., Nasholem T. 2001. The unexpected versatility of plants: organic nitrogen use and availability in terrestrial ecosystems. Oecologia 128: 305-316.

Mehta A., Mehta P., Chopra S. 1991. Effect of various nitrogenous sources on the production of pectolitic and cellulolytic enzymes by Fusarium oxysporum and F. moniliforme. Zentralblatt Fur Microbiologie 146: 393-398.

Sarosh B.R., Sivaramakrishnan S., Shetty H.S. 2005. Elicitation of defense related enzymes and resistance by L-methionine in pearl millet against downy mildew disease caused by Sclerospora graminicola. Plant Physiology and Biochemistry 43 (8): $808-815$. 
Singh D.L., Brinkerhoff A., Guinn G. 1971. Effect of alanine on development of Verticillium wilt of cotton cultivars with different levels of resistance. Phytopathology 61: 881-882.

Steinberg R.A. 1950. Symptoms of amino acids action on tobacco seedlings in aseptic culture. Journal of Agricultural Research 78: 733-741.

Steinberg R.A. 1952. Frenching symptoms produced in Nicotiana tabacum and N. russica with optical isomers of isoleucine and with Bacillus cereus toxin. Plant Physiology 27 (2): 302-308.

Tzeng D.D., Tzeng H.C., Chen R., Cheng A., Tsai C.C., Chen C., Hwang T., Yeh Y., DeVay J.E. 1996. The use of MR formulation as a novel and environmentally safe photodynamic fungicide for the control of powdery mildew. Crop Protection 15 (4): $341-347$.

Van Andel O.M. 1966. Amino acids and plant diseases. Annual Review of Phytopathology 4: 349-368.

Woltz S.S., Jones J.P. 1970. Effects of twenty natural amino acids on pathogenesis of Homestead 24 tomato caused by Fusarium oxysporum f. sp. lycopersici race 1 and 2. Florida State Horticultural Society 83: 175-179.

Wojdyła A.T. 2000. Efficacy of fungicides in the control of Sphaerotheca pannosa var. rosae on greenhouse rose cultivars and their influence on the growth and development of plants. Journal of Plant Protection Research 40 (1): 61-68.

Wojdyła A.T. 2008. Wpływ związków strobilurynowych na występowanie mączniaka prawdziwego róży (Sphaerotheca pannosa var. rosae). [Influence of strobilurin compounds on the development of Sphaerotheca pannosa var. rosae]. Zeszyty Problemowe Postępów Nauk Rolniczych 529: 257-262. 